\title{
Potential Applications of Extracellular Vesicles in Solid Organ Transplantation
}

\author{
Cristina Grange ${ }^{1}(0)$, Linda Bellucci ${ }^{2}$, Benedetta Bussolati ${ }^{2, *}$ and Andrea Ranghino ${ }^{1,3}$ \\ 1 Department of Medical Sciences, University of Turin, 10126 Turin, Italy; cristina.grange@unito.it (C.G.); \\ andrea.ranghino@unito.it (A.R.) \\ 2 Department of Molecular Biotechnology and Health Sciences, University of Turin; 10126 Turin, Italy; \\ linda.bellucci@unito.it \\ 3 SOD Nefrologia, Dialisi e Trapianto Rene, AOU Ospedali Riuniti, 60126 Ancona, Italy \\ * Correspondence: benedetta.bussolati@unito.it; Tel.: +39-011-6706453; Fax: +39-011-6631184
}

Received: 17 December 2019; Accepted: 5 February 2020; Published: 5 February 2020

\begin{abstract}
Extracellular vesicles (EVs) play an important role in cell-to-cell communication by delivering coding and non-coding RNA species and proteins to target cells. Recently, the therapeutic potential of EVs has been shown to extend to the field of solid organ transplantations. Mesenchymal stromal cell-derived EVs (MSC-EVs) in particular have been proposed as a new tool to improve graft survival, thanks to the modulation of tolerance toward the graft, and to their anti-fibrotic and pro-angiogenic effects. Moreover, MSC-EVs may reduce ischemia reperfusion injury, improving the recovery from acute damage. In addition, EVs currently considered helpful tools for preserving donor organs when administered before transplant in the context of hypothermic or normothermic perfusion machines. The addition of EVs to the perfusion solution, recently proposed for kidney, lung, and liver grafts, resulted in the amelioration of donor organ viability and functionality. EVs may therefore be of therapeutic interest in different aspects of the transplantation process for increasing the number of available organs and improving their long-term survival.
\end{abstract}

Keywords: exosomes; regenerative medicine; machinery perfusion; transplant; preconditioning

\section{Introduction}

Solid organ transplantation represents the gold standard treatment for patients with end-stage organ failure. Specifically, kidney transplantation has become a routine procedure because of its beneficial effects on patient survival and quality of life, together with its economic aspects [1]. Although the global observatory on donation and transplantation reported a total of 139,024 solid organ transplants worldwide with 90,306 kidneys in 2017, this met less than $10 \%$ of the global need [2]. Data from Eurotransplant [3], NHS-UK [4], and US registries [5] show that 141,568 patients are waiting for a transplant, $82 \%$ of which are kidney transplants. Therefore, the gap existing between the need for transplants and organ availability represents a major challenge to be addressed by scientific community [6]. To reduce this gap, novel strategies have to be explored. The main option being explored at present is the increase of the pool of deceased donors, including donors after circulatory death (DCDs), which actually represent about $20 \%$ of the deceased donors worldwide, and older donors with comorbidities such as hypertension, mild renal impairment, and death from cerebrovascular events (extended criteria donors, ECDs) [7]. Nevertheless, organs from DCDs and ECDs are more prone to developing an ischemic-reperfusion injury (IRI) compared to standard donors, and consequently represent an increased risk of primary non-function and delayed graft function (DGF) [8]. In addition, long-term graft survival is still a critical factor that needs to be improved. 
Among the different strategies in regenerative medicine, EVs have been recently recognized as a promising and innovative tool with which to accelerate tissue recovery after organ damage. EVs are a heterogeneous group of membranous vesicles that possess a central role in the mechanisms of cell-to-cell communication $[9,10]$. In the last decade, interest and knowledge in the field of EVs has increased enormously, and it is now well established that EVs may influence the function of target cells by transferring bioactive molecules and genetic materials, inducing epigenetic changes in recipient cells [11-13].

In this review, we present the current literature regarding the potential application of stem-cell-derived EVs, dissecting their possible application as an innovative therapeutic tool to precondition grafts before transplant as well as to prevent ischemic/reperfusion damage (Figure 1). In particular, we describe their use in pre-transplant solid organ preservation in association with normothermic and hypothermic perfusion machines. In addition, their role in the limitation of IRI is highlighted for kidney, liver, lung, and heart. Finally, we present their immunomodulatory properties in bone marrow transplantation.

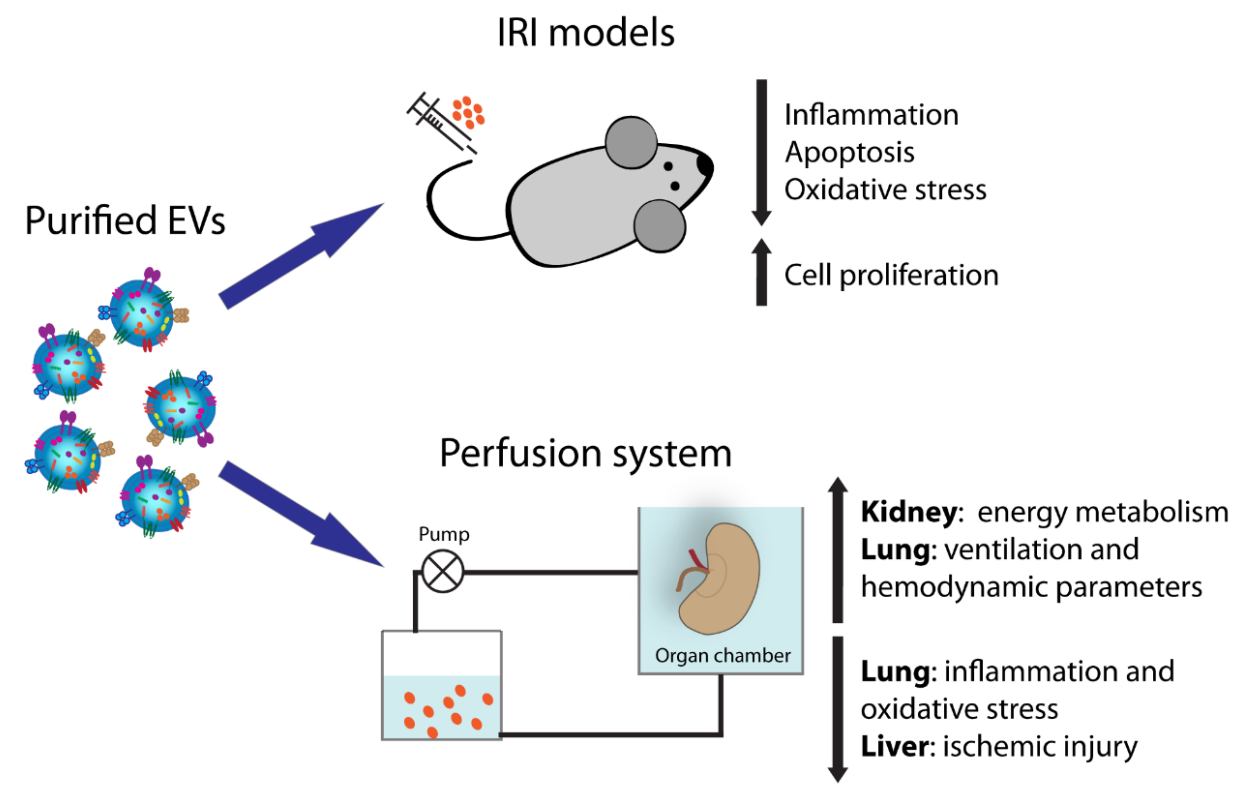

Figure 1. Extracellular vesicle (EV) activities in solid organ transplantation.

\section{Stem-Cell-Derived EVs and Regenerative Medicine}

EVs released by healthy cells are very heterogeneous in size and composition, and they can be classified based on their origin and dimension into two main categories: small EVs, ranging between 30 and $100 \mathrm{~nm}$, and large EVs, ranging between 50 and $1000 \mathrm{~nm}$ [14].

Among small EVs, exosomes are the most characterized vesicles, considered to originate from multivesicular bodies after their fusion with the cell membrane [15]. However, other subtypes of small EVs different from the multivesicular-body-derived exosomes have been identified, for instance after plasma membrane budding [14].

Large EVs, also called microvesicles/ectosomes, comprise different populations of vesicles originating from the budding of the plasma membrane [16]. The different EV populations express common and specific surface markers. For instance, tetraspanins such as CD9, CD81, and CD63 are mainly expressed by small EVs [14]. In addition, small EVs are characterized by the presence of molecules of the endosomal sorting complex required for transport (ESCRT), heat shock proteins (HSP70 and HSP90), and auxiliary proteins (ALIX, TSG101, and VPS4). In terms of variance, large EVs are specifically characterized by expression of the CD40 ligand $[17,18]$. The detailed composition of EV cargo has been deeply dissected and several databases collecting these results are now available, such as EVpedia [19], Exocarta [20], 
and Vesiclepedia [21]. EVs can be isolated from the majority of body fluids such as plasma and serum, amniotic and seminal fluids, saliva, urine, or nasal and bronchial lavage fluids [9,22].

Is important to take into consideration that a limitation to consistent $\mathrm{EV}$ characterization is the variability in EV isolation protocols. Depending on the size of EVs and on the fluids of origin, different techniques can be utilized, including ultra-high-speed centrifugation, polymer precipitation, immunoaffinity capture, or microfluidics-based techniques, among others [23]. Rigor criteria for EV isolation and characterization were recently proposed by the International Society for Extracellular Vesicles (ISEV) [14].

Stem-cell-derived EVs possess many characteristics in common with the originating cells; for instance, they carry some transcription factors classically expressed by stem cells, such as Nanog and Oct-4, as well as stem (CD133 and c-Kit) and mesenchymal markers (CD105, CD29, and CD73) [24]. It has been clearly demonstrated that stem-cell-derived EVs recapitulate the pro-regenerative capacity of the cells of origin and, in particular, those derived from mesenchymal stromal cells (MSCs) appear the ideal candidates to favor tissue regeneration. MSC-EVs may be isolated from MSCs derived from different adult tissues such as bone marrow, peripheral and cord blood, adipose tissue, or neonatal birth-associated tissues including placenta and umbilical cord [25]. Several studies have shown that MSC-EVs possess strong pro-regenerative properties using preclinical models of renal, lung, liver, and heart injuries, mimicking the beneficial effect of the cells themselves [14,26,27]. The activity of EVs mainly results in the reduction of apoptosis, oxidative stress, and inflammation and in increase of cell proliferation $[24,28,29]$.

\section{Normothermic and Hypothermic Perfusion Machines}

In order to increase the number of successful transplants, the use of machine perfusion is currently proposed to ameliorate the function of organs from marginal donors such as DCDs and ECDs. Dynamic perfusion of organs appears a useful strategy to evaluate pretransplant graft function, limiting the discard rate [30-32]. Moreover, this approach reduces the incidence of DGF in recipients receiving organs from ECDs and DCDs.

At present, dynamic machine perfusion can be done in hypothermic (HMP) or in normothermic (NMP) conditions with or without oxygen. Several studies have demonstrated that both HPM and NPM are useful in the assessment of organ viability prior to transplantation [32-34]. Specifically, HMP is able to reduce DGF and to increase the graft survival of organs harvested from ECDs, but conflicting results have been reported on the beneficial effects of HMP on grafts from DCDs [35-40]. Another beneficial effect of HMP is the removal of inflammatory mediators that may have detrimental effects on graft function. The delivery of oxygen added to the hypothermic perfusate may help to restore adenosine triphosphate (ATP) content [41-44]. Because of the unknown effects of this oxygenated perfusion on transplanted patients, a large international randomized controlled trial has been planned to investigate the beneficial effects of oxygenated short-term perfusion of kidneys from ECDs (Consortium for Organ Preservation in Europe COPE Trials) [45].

As oxygenated machine perfusion, NMP may protect organs from IRI by restoring ATP levels [46,47]. In particular, ex vivo normothermic perfusion, consisting of circulation through the harvested organs of warm oxygenated red-cell-based solution, is able to restore the metabolism and function of the graft prior to transplantation [48-50]. NMP could offer a better evaluation of organ viability compared to HMP, especially in kidney and liver grafts because of urine or bile production, together with a better preservation of graft function [51].

Both HMP and NMP allow the delivery of targeted therapies to organs prior to transplantation. In particular, these approaches offer the potential to explore the effects of several therapeutic strategies, such as gene-silencing, nanoparticles, and cell therapies, in a fully functioning graft [52-57]. 


\section{EVs for Kidney Transplant}

An innovative EV-based application for organ preservation is the use of EVs in the perfusion solution. A first report in the literature recently demonstrated that EVs released by MSCs, delivered in the perfusate during organ cold perfusion $(4 \mathrm{~h})$, preserve and protect kidney function. Histological and genetic analyses on EV-treated kidneys revealed upregulation of enzymes involved in energy metabolism and reduction of global ischemic damage. In addition, the analysis of lactate, LDH, and glucose in the effluent fluid confirmed a greater use of energy substrates by EV-treated kidneys, supporting the report of improved functionality (Table 1) [58].

Moreover, an extensive number of publications have highlighted the beneficial effect of EVs in preclinical models of IRI, further implying their possible application to limit organ damage [9]. In particular, EVs isolated from different MSC sources [59-62] have been shown to accelerate renal recovery after damage, promoting cell proliferation and blocking inflammation and apoptosis when intravenously injected after IR damage [63]. The mechanisms of action reported appear different between the EV sources: MSC-EVs obtained from Wharton's jelly stimulate tubular proliferation and reduce inflammation and apoptosis via mitochondrial protection [61,62], while those from cord blood promote tubular dedifferentiation and proliferation by the transfer of human HGF [60]. Moreover, EVs isolated from bone marrow MSCs were protective mainly by suppressing inflammation when injected under the renal capsule [64]. In addition, EVs obtained from MSCs isolated from glomeruli have also been demonstrated to be capable of reducing ischemic damage [65].

Moreover, a recent publication demonstrated that EVs isolated from the venal perfusate of rats subjected to remote ischemia preconditioning ameliorated renal function when injected into another animal with IRI. To explore the underlying mechanism, authors tested in vivo, in the same IRI model, the effect of EVs released by human proximal tubular cells cultured in hypoxia, supporting the thesis that remote ischemia precondition activates a repairing program into tubular cells by the release of pro-regenerative EVs [66].

Whereas all the studies mentioned above evaluated classical ischemic damage in models of renal artery clamping, Wu and co-workers tested for the first time the effect of EVs in a rat model of IRI after DCD renal transplantation [67]. The authors confirmed that Wharton's jelly MSC-EVs, intravenously injected after renal transplantation, mitigated renal damage, improving survival and function. In particular, MSC-EVs were shown to reduce cell apoptosis and inflammation, to stimulate HGF production, and subsequently to alleviate fibrosis [67].

Table 1. List of EV applications for organ preconditioning. Abbreviations: bone marrow (BM), human liver stem cells (HLSCs).

\begin{tabular}{|c|c|c|c|c|c|}
\hline Organs & EV Sources & $\begin{array}{l}\text { Type of } \\
\text { Perfusion }\end{array}$ & $\begin{array}{c}\text { Time of } \\
\text { Preconditioning }\end{array}$ & Results & References \\
\hline Kidney & BM-MSCs & Hypothermic & $4 \mathrm{~h}$ & Preservation and protection & Gregorini et al. [58] \\
\hline Lung & BM-MSCs & Normothermic & $6 \mathrm{~h}$ & $\begin{array}{l}\text { Improvement of ventilation and } \\
\text { hemodynamic parameters }\end{array}$ & Gennai et al. [68] \\
\hline Lung & BM-MSCs & Normothermic & $6 \mathrm{~h}$ & $\begin{array}{l}\text { Restoring permeability and } \\
\text { reduction of inflammation }\end{array}$ & Park et al. [69] \\
\hline Lung & BM-MSCs & Normothermic & $1 \mathrm{~h}$ & $\begin{array}{l}\text { Attenuation of IR dysfunction and } \\
\text { immunomodulation }\end{array}$ & Stone et al. [70] \\
\hline Lung & BM-MSCs & Normothermic & $3 \mathrm{~h}$ & $\begin{array}{c}\text { Reduction of inflammation and } \\
\text { oxidative stress }\end{array}$ & Lonati et al. [71] \\
\hline Liver & HLSCs & Normothermic & $4 \mathrm{~h}$ & $\begin{array}{l}\text { Limitation of the progression of } \\
\text { ischemic injury }\end{array}$ & Rigo et al. [72] \\
\hline
\end{tabular}

\section{EVs for Lung Transplantation}

Adult lung transplantation is considered the most effective strategy for end-stage pulmonary disease, although the reported 5-year survival rate is only 50\% [73]. Infections, immunomodulation, and IRI are in fact some of the aspects involved in lung transplant failure [74]. Through ex vivo lung perfusion, donor lungs can be evaluated and reconditioned, while organs are perfused and ventilated [75]. 
The use of MSC-EVs has been proposed as a valid alternative for the rehabilitation of marginal human lungs [68]. Upon administering MSC-EVs in the perfusion fluid, a dose-dependent increase of alveolar fluid clearance, a decrease of lung weight gain, and an improvement of airway and hemodynamic parameters were observed as compared to perfusion alone (Table 2). Moreover, the study showed that CD44 was involved in the EV uptake mechanism, as the efficacy of MSC-EVs decreased with the administration of anti-CD44 antibody.

A significant improvement of inflammatory conditions has also been ascribed to the EV effect on lung bacterial infections. For example, MSC-EVs have been demonstrated to be effective in restoring lung protein permeability and reducing inflammation in Escherichia-coli-endotoxin-induced acute lung injury in mice. In particular, MSC-EV treatment restored protein permeability and reduced inflammation, extravascular lung water, and total protein levels in the bronchoalveolar lavage fluid, demonstrating a reduction in pulmonary edema [76]. On this path, in a recent work, the effects of MSC-EVs were investigated in an ex vivo perfused human lung model, injured with severe E. coli pneumonia [69]. The paper confirmed a significant increase of alveolar fluid clearance and decrease in protein permeability, as well as the lowering of the bacterial load and the neutrophil count in the injured alveolus (Table 2). MSC pretreatment with a toll-like-receptor 3 agonist before the isolation of EVs increased their bactericidal activity.

Moreover, Stone and colleagues demonstrated the attenuation of IR dysfunction in lungs after treatment with MSC-EVs both in vivo and in ex vivo perfusion systems [70]. In particular, they observed a decrease of pro-inflammatory cytokines and upregulation of keratinocyte growth factor, PGE2, and IL-10. Recently, in a mouse model of ex vivo lung perfusion, EV-treated organs showed decreased vascular resistance and a rise of perfusate nitric oxide metabolites. Moreover, EV treatment prevented the reduction in pulmonary ATP and increased the medium-high-molecular-weight hyaluronan in the perfusate. The genes modulated in the pulmonary tissue by EV administration were involved in anti-inflammatory and anti-oxidative stress pathways [71].

\section{EVs for Liver Transplantation}

The use of EVs released by stem cells as an innovative option to improve the viability of pre-transplant livers was recently assessed in a model of ex vivo rat liver NMP. HLSC-EVs (EVs isolated from human liver stem cells) were added to perfusate $15 \mathrm{~min}$ after the initiation of NMP and administered for $4 \mathrm{~h}$ within the perfusate. The results showed that HLSC-EVs limited the progression of ischemic injury, with a significant reduction of the levels of aspartate aminotransferase and alanine aminotransferase and a decrease of histological damage compared with results of NMP alone (Table 2) [72]. Moreover, the authors demonstrated that HLSC-EVs were uptaken by hepatocytes, supporting the thesis that EVs may recondition liver cells before transplantation [72].

Moreover, the potential therapeutic use of stem-cell-derived-EVs for liver regeneration, has been also clearly demonstrated in pre-clinical models of liver IRI. In fact, hepatic ischemia and related inflammation should be limited to avoid complication after liver transplantation [77]. The intravenous injection of murine MSC-EVs prior to IRI reduced the area of necrosis and apoptosis with concomitant increased liver function [77]. In addition, MSC-EVs have been shown to limit liver inflammation and oxidative stress [77]. Similar results were obtained using EVs isolated from MSCs from inducible pluripotent stem cells [78] or bone marrow [79]. Recently, Yao et al. demonstrated that human umbilical cord MSC-EVs protect hepatic apoptosis post-IRI, modulating neutrophils and reducing oxidative stress [80].

\section{Stem-Cell-Derived EVs as Future Therapeutics in Heart Transplantation}

EVs have been shown to be powerful allies against cardiovascular damage. Some important interconnected effects related to EVs could improve the success of a heart transplantation, including immunomodulatory properties, the improvement of heart function and vessel formation, and the amelioration of myocardial function during IRI [81]. 
Much evidence confirms the hypothesis that cardiac progenitor cells release pro-regenerative and anti-fibrotic EVs in response to hypoxic conditions [82,83], mainly due to their miRNA cargo [82]. Moreover, cardiac-progenitor-cell-derived EVs, released into their environment, can stimulate migration of endothelial cells [84] and inhibit both cardiac fibroblast activation and collagen synthesis [85].

In parallel, MSC-EV treatment has also been proven as a therapeutic option to limit ischemic damage in the heart. In particular, MSC-EV administration increased phosphorylated-Akt and phosphorylated-GSK-3 $\beta$, as well as ATP/NADH level, and could reduce phosphorylated-c-JNK and inflammatory response in ischemic/reperfused hearts [86].

\section{EVs for Islet Transplantation}

Today, there are still many factors that limit the success of pancreatic islet transplantation, including islet source limitation, sub-optimal engraftment, lack of oxygen and blood supply for transplanted islets, and immune rejection [87]. In parallel with the other described organs, MSC-EVs may also be of benefit for islet transplantation.

One of the primary reasons for apoptosis and reduced beta-cell function in transplants is hypoxic damage. Recently, EVs from human-umbilical-cord-derived MSCs were shown to have a therapeutic effect on the survival and function of neonatal porcine islets exposed to hypoxia [88]. The use of EVs, in comparison with medium alone, enhanced the yield and survival of porcine islets, and showed an improvement of the function through the amelioration of mitochondrial respiration efficiency [88].

In addition, Di Wen and colleagues showed that MSC-EV administration through delivery of small RNAs promoted islet function and inhibited immune rejection [89]. In a mouse model, they used MSC-EVs transfected with shFas and anti-miR-375 in order to silence Fas and miR-375 in human islets, observing an improvement of islet viability and function. Moreover, the authors observed the inhibition of peripheral blood mononuclear cell proliferation and the enhancement of T-cell regulatory function. Based on these works, EVs from different sources appear of interest to increase the possibility of successful islet transplantation.

\section{Role of MSC-EVs in the Amelioration of Graft Versus Host Disease}

EVs derived from bone marrow MSCs possess an immunosuppressive potential that can be harnessed to treat graft versus host disease (GVHD), which today represents the greatest complication after allogeneic transplantation. The majority of the literature on the subject has generically focused on the effects of the whole MSC secretome, including EVs and soluble factors. Recently, the specific role of EVs has been highlighted, showing an effect on innate and adaptive immunity (Table 2).

For example, in 2005, Aggarwal and Pittenger highlighted that the secretome, released by MSCs, be responsible for modulation of immune reaction, involved in GVHD [90]. In fact, if co-cultured with purified subpopulations of immune cells, human MSCs were able to switch an inflammatory response into a tolerant phenotype. In particular, MSCs induced mature dendritic cells type 1 and type 2 to decrease TNF- $\alpha$ and to increase IL-10 secretion, respectively; they also induced Thelper 1 lymphocytes and natural killer cells to decrease interferon (IFN) $\gamma$ secretion. In addition, they enhanced a regulatory response, causing the Thelper 2 cells to increase secretion of IL-4, increasing the proportion of regulatory T cells and producing prostaglandin (PG) E2 [90].

Moreover, soluble factors released by MSCs, such as vascular endothelial growth factor and IL-6, were shown to inhibit T-cell proliferation and to be involved in a partial inhibition of dendritic cell differentiation [91]. Selmani et al. not only confirmed the role of the MSC secretome in modulating innate immunity, but they also sustained its strong modulation of adaptive immunity [92]. Moreover, they reported that the nonclassic HLA class I molecule HLA-G is responsible for the immunomodulatory properties of MSCs [92].

In a recent work, it was shown that bone marrow MSC-EVs recapitulate the therapeutic effects of the cells against acute GVHD [93]. A systemic infusion of MSC-EVs in mice with acute GVHD was associated with the suppression of $\mathrm{CD} 4^{+}$and $\mathrm{CD} 8^{+} \mathrm{T}$ cells and with the preservation of circulating 
naive T cells, possibly due to the unique microRNA profiles of MSC-EVs. The analysis on microRNA cargo in MSC-EVs identified that their target genes were involved in regulation of the cell cycle, T-cell receptor signaling, and GVHD [93]. These findings suggest that MSC-EVs could be a new potential therapeutic option to prevent GVHD, to be tested in future clinical trials.

Table 2. Immunomodulatory properties of MSC secretome/EVs.

\begin{tabular}{|c|c|c|c|c|}
\hline Cell Types & Actions & Mechanisms & Effector & References \\
\hline T lymphocytes & $\begin{array}{c}\text { Decrease of TH1 secretion of } \\
\text { IFN- } \gamma \text { [91] } \\
\text { Increase of TH2 secretion of } \\
\text { IL-4 [91] } \\
\text { Increase of the proportion of } \\
\text { T-regs [91] } \\
\text { Suppression of T-naïve } \\
\text { differentiation [94] } \\
\text { Decrease in proliferation and } \\
\text { migration [94] } \\
\text { Decrease of CD4 }{ }^{+} \text {CD } 8^{+}[94]\end{array}$ & $\begin{array}{c}\text { Constitutive production } \\
\text { of COX2 and PGE2 } \\
\text { [91-93] } \\
\text { Secretion of TGF- } \beta \text { [91] } \\
\text { Secretion of soluble } \\
\text { HLA-G5 [93] }\end{array}$ & $\begin{array}{c}\text { Secretome [91-93] } \\
\text { EVs [94] }\end{array}$ & $\begin{array}{l}\text { S. Aggarwal et al. [91] } \\
\text { Z Selmani et al. [93] } \\
\text { S. Fujii et al. [94] }\end{array}$ \\
\hline DC & $\begin{array}{c}\text { Reversion of maturation of } \\
\text { DCs [92] } \\
\text { Decrease DC1 production of } \\
\text { TNF- } \alpha \text { [91] } \\
\text { Increase DC2 production of } \\
\text { IL-10 [91] }\end{array}$ & Secretion of IL-6 [91] & Secretome $[91,92]$ & $\begin{array}{l}\text { S. Aggarwal et al. [91] } \\
\text { F. Djouad et al. [92] }\end{array}$ \\
\hline NK & $\begin{array}{c}\text { Inhibition [91] } \\
\text { Alteration of secreted } \\
\text { cytokines [91] }\end{array}$ & $\begin{array}{c}\text { Secretion of indoleamine } \\
\text { 2,3-deoxygenase [91] } \\
\text { Secretion of PGE2 [91] } \\
\text { Secretion of TGF- } \beta \text { [91] }\end{array}$ & Secretome [91] & S. Aggarwal et al. [91] \\
\hline
\end{tabular}

\section{Conclusions}

The organ demand is continuously increasing and there is a constant need to expand the pool of donors. Increasing organ availability represents a major challenge in the field of transplantation.

Among the most recent innovative strategies, the use of EVs seems very promising. The application of EVs in the perfusion solution, recently proposed for kidney, lung, and liver grafts, results in the amelioration of donor organ viability and functionality. Moreover, consolidated results describe the beneficial effects of EV administration in several preclinical models of IRI. In particular, stem-cell-derived EVs have displayed strong pro-regenerative properties in different models of renal, lung, liver, and heart injuries. IRI is an unavoidable consequence after transplants and the severity of this phenomenon affects the graft outcome, leading to delayed graft function, graft rejection, chronic rejection, and chronic graft dysfunction. The development of strategies to limit the progression of IRI is fundamental for the success of transplants. Altogether, EVs appear the ideal candidate to target different aspects during transplantation process.

Author Contributions: Writing—original draft preparation, A.R., C.G., L.B. and B.B.; writing—review and editing, L.B., C.G. and B.B.; funding acquisition, B.B. All authors have read and agreed to the published version of the manuscript.

Funding: This research was funded by, Regione Piemonte POR FESR 2014/2020—Grant "Bando Piattaforma Tecnologica Salute e Benessere", Project "Terapie Avanzate per Processi Fibrotici Cronici (EVER)".

Conflicts of Interest: The authors declare no conflict of interest.

\section{References}

1. Wolfe, R.A.; Ashby, V.B.; Milford, E.L.; Ojo, A.O.; Ettenger, R.E.; Agodoa, L.Y.C.; Held, P.J.; Port, F.K. Comparison of mortality in all patients on dialysis, patients on dialysis awaiting transplantation, and recipients of a first cadaveric transplant. N. Engl. J. Med. 1999, 341, 1725-1730. [CrossRef] [PubMed]

2. 2017 Global Report-GODT. Available online: http://www.transplant-observatory.org/download/2017activity-data-report/ (accessed on 2 December 2019). 
3. Branger, P.; Undine, S. Eurotransplant Annual Report 2018. 2018. Available online: https://www.eurotransplant. org/organs/kidney/ (accessed on 5 February 2020).

4. NHS Organ Donation and Transplantation Activity Report 2018/19. $2019 . \quad$ Available online: https://www.organdonation.nhs.uk/helping-you-to-decide/about-organ-donation/statistics-aboutorgan-donation/transplant-activity-report/ (accessed on 5 February 2020).

5. Hart, A.; Smith, J.M.; Skeans, M.A.; Gustafson, S.K.; Wilk, A.R.; Castro, S.; Robinson, A.; Wainright, J.L.; Snyder, J.J.; Kasiske, B.L.; et al. OPTN/SRTR 2017 Annual Data Report: Kidney. Am. J. Transplant. 2019, 19, 19-123. [CrossRef] [PubMed]

6. Abramowicz, D.; Oberbauer, R.; Heemann, U.; Viklicky, O.; Peruzzi, L.; Mariat, C.; Crespo, M.; Budde, K.; Oniscu, G.C. Recent advances in kidney transplantation: A viewpoint from the Descartes advisory board. Nephrol. Dial. Transplant. 2018, 33, 1699-1707. [CrossRef] [PubMed]

7. Sørensen, S.S. Rates of renal transplantations in the elderly-data from Europe and the US. Transplant. Rev. 2015, 29, 193-196. [CrossRef]

8. Nashan, B.; Abbud-Filho, M.; Citterio, F. Prediction, prevention, and management of delayed graft function: Where are we now? Clin. Transplant. 2016, 30, 1198-1208. [CrossRef]

9. Grange, C.; Skovronova, R.; Marabese, F.; Bussolati, B. Stem Cell-Derived Extracellular Vesicles and Kidney Regeneration. Cells 2019, 8, 1240. [CrossRef]

10. Quesenberry, P.J.; Aliotta, J.; Deregibus, M.C.; Camussi, G. Role of extracellular RNA-carrying vesicles in cell differentiation and reprogramming. Stem Cell Res. Ther. 2015, 6, 1-10. [CrossRef]

11. Valadi, H.; Ekström, K.; Bossios, A.; Sjöstrand, M.; Lee, J.J.; Lötvall, J.O. Exosome-mediated transfer of mRNAs and microRNAs is a novel mechanism of genetic exchange between cells. Nat. Cell Biol. 2007, 9, 654-659. [CrossRef]

12. Ratajczak, M.Z.; Ratajczak, J. Horizontal transfer of RNA and proteins between cells by extracellular microvesicles: 14 years later. Clin. Transl. Med. 2016, 5. [CrossRef]

13. Deregibus, M.C.; Cantaluppi, V.; Calogero, R.; Lo Iacono, M.; Tetta, C.; Biancone, L.; Bruno, S.; Bussolati, B.; Camussi, G. Endothelial progenitor cell—Derived microvesicles activate an angiogenic program in endothelial cells by a horizontal transfer of mRNA. Blood 2007, 110, 2440-2448. [CrossRef]

14. Théry, C.; Witwer, K.W.; Aikawa, E.; Alcaraz, M.J.; Anderson, J.D.; Andriantsitohaina, R.; Antoniou, A.; Arab, T.; Archer, F.; Atkin-Smith, G.K.; et al. Minimal information for studies of extracellular vesicles 2018 (MISEV2018): A position statement of the International Society for Extracellular Vesicles and update of the MISEV2014 guidelines. J. Extracell. Vesicles 2018, 7, 1535750. [CrossRef] [PubMed]

15. Mathivanan, S.; Ji, H.; Simpson, R.J. Exosomes: Extracellular organelles important in intercellular communication. J. Proteomics 2010, 73, 1907-1920. [CrossRef] [PubMed]

16. van der Pol, E.; Böing, A.N.; Harrison, P.; Sturk, A.; Nieuwland, R. Classification, functions, and clinical relevance of extracellular vesicles. Pharmacol. Rev. 2012, 64, 676-705. [CrossRef] [PubMed]

17. Mobarrez, F.; Sjövik, C.; Soop, A.; Hållström, L.; Frostell, C.; Pisetsky, D.S.; Wallén, H. CD40L expression in plasma of volunteers following LPS administration: A comparison between assay of CD40L on platelet microvesicles and soluble CD40L. Platelets 2015, 26, 486-490. [CrossRef] [PubMed]

18. Jeppesen, D.K.; Fenix, A.M.; Franklin, J.L.; Higginbotham, J.N.; Zhang, Q.; Zimmerman, L.J.; Liebler, D.C.; Ping, J.; Liu, Q.; Evans, R.; et al. Reassessment of Exosome Composition. Cell 2019, 177, 428-445.e18. [CrossRef] [PubMed]

19. Kim, D.K.; Kang, B.; Kim, O.Y.; Choi, D.S.; Lee, J.; Kim, S.R.; Go, G.; Yoon, Y.J.; Kim, J.H.; Jang, S.C.; et al. EVpedia: An integrated database of high-throughput data for systemic analyses of extracellular vesicles. J. Extracell. Vesicles 2013, 2,1-7. [CrossRef]

20. Mathivanan, S.; Fahner, C.J.; Reid, G.E.; Simpson, R.J. ExoCarta 2012: Database of exosomal proteins, RNA and lipids. Nucleic Acids Res. 2012, 40, D1241-4. [CrossRef]

21. Kalra, H.; Simpson, R.J.; Ji, H.; Aikawa, E.; Altevogt, P.; Askenase, P.; Bond, V.C.; Borràs, F.E.; Breakefield, X.; Budnik, V.; et al. Vesiclepedia: A Compendium for Extracellular Vesicles with Continuous Community Annotation. PLoS Biol. 2012, 10, 8-12. [CrossRef] [PubMed]

22. Keller, S.; Ridinger, J.; Rupp, A.K.; Janssen, J.W.G.; Altevogt, P. Body fluid derived exosomes as a novel template for clinical diagnostics. J. Transl. Med. 2011, 9, 86. [CrossRef] 
23. Yang, X.-X.; Sun, C.; Wang, L.; Guo, X.-L. New insight into isolation, identification techniques and medical applications of exosomes. J. Control. Release 2019, 308, 119-129. [CrossRef]

24. Bruno, S.; Chiabotto, G.; Favaro, E.; Deregibus, M.C.; Camussi, G. Role of extracellular vesicles in stem cell biology. Am. J. Physiol. Cell Physiol. 2019, 317, C303-C313. [CrossRef] [PubMed]

25. Grange, C.; Tritta, S.; Tapparo, M.; Cedrino, M.; Tetta, C.; Camussi, G.; Brizzi, M.F. Stem cell-derived extracellular vesicles inhibit and revert fibrosis progression in a mouse model of diabetic nephropathy. Sci. Rep. 2019, 9, 4468. [CrossRef] [PubMed]

26. Heldring, N.; Mäger, I.; Wood, M.J.A.; Le Blanc, K.; Andaloussi, S.E.L. Therapeutic Potential of Multipotent Mesenchymal Stromal Cells and Their Extracellular Vesicles. Hum. Gene Ther. 2015, 26, 506-517. [CrossRef]

27. Ferreira, J.R.; Teixeira, G.Q.; Santos, S.G.; Barbosa, M.A.; Almeida-Porada, G.; Gonçalves, R.M. Mesenchymal Stromal Cell Secretome: Influencing Therapeutic Potential by Cellular Pre-conditioning. Front. Immunol. 2018, 9, 2837. [CrossRef]

28. Collino, F.; Bruno, S.; Incarnato, D.; Dettori, D.; Neri, F.; Provero, P.; Pomatto, M.; Oliviero, S.; Tetta, C.; Quesenberry, P.J.; et al. AKI recovery induced by mesenchymal stromal cell-derived extracellular vesicles carrying micrornas. J. Am. Soc. Nephrol. 2015, 26, 2349-2360. [CrossRef] [PubMed]

29. György, B.; Szabó, T.G.; Pásztói, M.; Pál, Z.; Misják, P.; Aradi, B.; László, V.; Pállinger, É.; Pap, E.; Kittel, Á.; et al. Membrane vesicles, current state-of-the-art: Emerging role of extracellular vesicles. Cell. Mol. Life Sci. 2011, 68, 2667-2688. [CrossRef]

30. Matsuno, N.; Konno, O.; Mejit, A.; Jyojima, Y.; Akashi, I.; Nakamura, Y.; Iwamoto, H.; Hama, K.; Iwahori, T.; Ashizawa, T.; et al. Application of machine perfusion preservation as a viability test for marginal kidney graft. Transplantation 2006, 82, 1425-1428. [CrossRef]

31. Bissolati, M.; Gazzetta, P.G.; Caldara, R.; Guarneri, G.; Adamenko, O.; Giannone, F.; Mazza, M.; Maggi, G.; Tomanin, D.; Rosati, R.; et al. Renal Resistance Trend during Hypothermic Machine Perfusion Is More Predictive of Postoperative Outcome Than Biopsy Score: Preliminary Experience in 35 Consecutive Kidney Transplantations. Artif. Organs 2018, 42, 714-722. [CrossRef]

32. Gelpi, R.; Paredes, D.; Rodríguez-Villar, C.; Roque, R.; Ruiz, A.; Adalia, R.; Peri-Cusí, L.; Sole, M.; Oppenheimer, F.; Diekmann, F. The development of a predictive model of graft function in uncontrolled donors after circulatory death: Validity of a pulsatile renal preservation machine cut-off value for kidney acceptance. Nephrol. Dial. Transplant. 2019, 34, 531-538. [CrossRef]

33. Hameed, A.M.; Pleass, H.C.; Wong, G.; Hawthorne, W.J. Maximizing kidneys for transplantation using machine perfusion: From the past to the future: A comprehensive systematic review and meta-analysis. Medicine 2016, 95, e5083. [CrossRef]

34. Brat, A.; Pol, R.A.; Leuvenink, H.G.D. Novel preservation methods to increase the quality of older kidneys. Curr. Opin. Organ Transplant. 2015, 20, 438-443. [CrossRef] [PubMed]

35. Gallinat, A.; Moers, C.; Smits, J.M.; Strelniece, A.; Pirenne, J.; Ploeg, R.J.; Paul, A.; Treckmann, J. Machine perfusion versus static cold storage in expanded criteria donor kidney transplantation: 3-year follow-up data. Transpl. Int. 2013, 26, 52-53. [CrossRef] [PubMed]

36. Ali, F.; Dua, A.; Cronin, D.C. Changing paradigms in organ preservation and resuscitation. Curr. Opin. Organ Transplant. 2015, 20, 152-158. [CrossRef] [PubMed]

37. Matos, A.C.C.; Requiao Moura, L.R.; Borrelli, M.; Nogueira, M.; Clarizia, G.; Ongaro, P.; Durão, M.S.; Pacheco-Silva, A. Impact of machine perfusion after long static cold storage on delayed graft function incidence and duration and time to hospital discharge. Clin. Transplant. 2018, 32. [CrossRef] [PubMed]

38. Tedesco-Silva, H.; Mello Offerni, J.C.; Ayres Carneiro, V.; Ivani de Paula, M.; Neto, E.D.; Brambate Carvalhinho Lemos, F.; Requião Moura, L.R.; Pacheco eSilva Filho, A.; de Morais Cunha, M.d.F.; Francisco da Silva, E.; et al. Randomized Trial of Machine Perfusion Versus Cold Storage in Recipients of Deceased Donor Kidney Transplants with High Incidence of Delayed Graft Function. Transplant. Direct 2017, 3, e155. [CrossRef] [PubMed]

39. Delsuc, C.; Faure, A.; Berthiller, J.; Dorez, D.; Matillon, X.; Meas-Yedid, V.; Floccard, B.; Marcotte, G.; Labeye, V.; Rabeyrin, M.; et al. Uncontrolled donation after circulatory death: Comparison of two kidney preservation protocols on graft outcomes. BMC Nephrol. 2018, 19, 1-9. [CrossRef] [PubMed] 
40. Czigany, Z.; Lurje, I.; Tolba, R.H.; Neumann, U.P.; Tacke, F.; Lurje, G. Machine perfusion for liver transplantation in the era of marginal organs-New kids on the block. Liver Int. 2019, 39, $228-249$. [CrossRef]

41. Kron, P.; Schlegel, A.; De Rougemont, O.; Oberkofler, C.E.; Clavien, P.A.; Dutkowski, P. Short, cool, and well oxygenated-HOPE for kidney transplantation in a rodent model. Ann. Surg. 2016, 264, 815-822. [CrossRef]

42. Minor, T.; Paul, A. Hypothermic reconditioning in organ transplantation. Curr. Opin. Organ Transplant. 2013, 18, 161-167. [CrossRef]

43. Kaths, J.M.; Paul, A.; Robinson, L.A.; Selzner, M. Ex vivo machine perfusion for renal graft preservation. Transplant. Rev. 2018, 32,1-9. [CrossRef]

44. Solhjou, Z.; Athar, H.; Xu, Q.; Abdi, R. Emerging therapies targeting intra-organ inflammation in transplantation. Am. J. Transplant. 2015, 15, 305-311. [CrossRef] [PubMed]

45. COPE-Trials. Available online: http://cope-eu.com/workprogramme/trials.html (accessed on 2 December 2019).

46. Hessheimer, A.J.; Riquelme, F.; Fundora-Suárez, Y.; García Pérez, R.; Fondevila, C. Normothermic perfusion and outcomes after liver transplantation. Transplant. Rev. 2019, 33, 200-208. [CrossRef] [PubMed]

47. Palomo-López, N.; Martín-Sastre, S.; Martín-Villén, L.; Ruiz de Azúa-López, Z.; Solis-Clavijo, D.; Caballero-Gálvez, S.; Carballo-Caro, J.M.; Egea-Guerrero, J.J. Normothermic Regional Perfusion and Donation after Circulatory Death (Controlled and Uncontrolled): Metabolic Differences and Kidney Transplantation Evolution. Transplant. Proc. 2019, 51, 3044-3046. [CrossRef] [PubMed]

48. Hosgood, S.A.; Saeb-Parsy, K.; Wilson, C.; Callaghan, C.; Collett, D.; Nicholson, M.L. Protocol of a randomised controlled, open-label trial of ex vivo normothermic perfusion versus static cold storage in donation after circulatory death renal transplantation. BMJ Open 2017, 7, 1-7. [CrossRef] [PubMed]

49. Hosgood, S.A.; Thompson, E.; Moore, T.; Wilson, C.H.; Nicholson, M.L. Normothermic machine perfusion for the assessment and transplantation of declined human kidneys from donation after circulatory death donors. Br. J. Surg. 2018, 105, 388-394. [CrossRef]

50. Laing, R.W.; Mergental, H.; Yap, C.; Kirkham, A.; Whilku, M.; Barton, D.; Curbishley, S.; Boteon, Y.L.; Neil, D.A.; Hübscher, S.G.; et al. Viability testing and transplantation of marginal livers (VITTAL) using normothermic machine perfusion: Study protocol for an open-label, non-randomised, prospective, single-arm trial. BMJ Open 2017, 7, 1-15.

51. Weissenbacher, A.; Hunter, J. Normothermic machine perfusion of the kidney. Curr. Opin. Organ Transplant. 2017, 22, 571-576. [CrossRef]

52. Brasile, L.; Stubenitsky, B.M.; Booster, M.H.; Arenada, D.; Haisch, C.; Kootstra, G. Transfection and transgene expression in a human kidney during ex vivo warm perfusion. Transplant. Proc. 2002, 34, 2624. [CrossRef]

53. Chen, J.; Braet, F.; Brodsky, S.; Weinstein, T.; Romanov, V.; Noiri, E.; Goligorsky, M.S. VEGF-induced mobilization of caveolae and increase in permeability of endothelial cells. Am. J. Physiol. Cell Physiol. 2002, 282, C1053-C1063. [CrossRef]

54. Chen, J.; Vemuri, C.; Palekar, R.U.; Gaut, J.P.; Goette, M.; Hu, L.; Cui, G.; Zhang, H.; Wickline, S.A. Antithrombin nanoparticles improve kidney reperfusion and protect kidney function after ischemia-reperfusion injury. Am. J. Physiol. Ren. Physiol. 2015, 308, F765-F773. [CrossRef]

55. DiRito, J.R.; Hosgood, S.A.; Tietjen, G.T.; Nicholson, M.L. The future of marginal kidney repair in the context of normothermic machine perfusion. Am. J. Transplant. 2018, 18, 2400-2408. [CrossRef] [PubMed]

56. Hamaoui, K.; Gowers, S.; Boutelle, M.; Cook, T.H.; Hanna, G.; Darzi, A.; Smith, R.; Dorling, A.; Papalois, V. Organ Pretreatment with Cytotopic Endothelial Localizing Peptides to Ameliorate Microvascular Thrombosis and Perfusion Deficits in Ex Vivo Renal Hemoreperfusion Models. Transplantation 2016, 100, e128-e139. [CrossRef] [PubMed]

57. Hamaoui, K.; Aftab, A.; Gowers, S.; Boutelle, M.; Cook, T.; Rudd, D.; Dobson, G.P.; Papalois, V. An ex vivo comparison of adenosine and lidocaine solution and University of Wisconsin solution for hypothermic machine perfusion of porcine kidneys: Potential for development. J. Surg. Res. 2017, 208, 219-229. [CrossRef] [PubMed]

58. Gregorini, M.; Corradetti, V.; Francesca, E.; Rocca, C.; Milanesi, S.; Peloso, A.; Canevari, S.; Cecco, L.D.; Dugo, M.; Antonietta, M.; et al. Perfusion of isolated rat kidney with Mesenchymal Stromal Cells/Extracellular Vesicles prevents ischaemic injury MSC viability. J. Cell Mol. Med. 2017, 21, 3381-3393. [CrossRef] 
59. Gatti, S.; Bruno, S.; Deregibus, M.C.; Sordi, A.; Cantaluppi, V.; Tetta, C.; Camussi, G. Microvesicles derived from human adult mesenchymal stem cells protect against ischaemia-reperfusion-induced acute and chronic kidney injury. Nephrol. Dial. Transplant. 2011, 26, 1474-1483. [CrossRef]

60. Gu, D.; Zou, X.; Ju, G.; Zhang, G.; Bao, E.; Zhu, Y. Mesenchymal Stromal Cells Derived Extracellular Vesicles Ameliorate Acute Renal Ischemia Reperfusion Injury by Inhibition of Mitochondrial Fission through MIR-30. Stem Cells Int. 2016, 2016, 2093940. [CrossRef]

61. Ju, G.Q.; Cheng, J.; Zhong, L.; Wu, S.; Zou, X.Y.; Zhang, G.Y.; Gu, D.; Miao, S.; Zhu, Y.J.; Sun, J.; et al. Microvesicles derived from human umbilical cord mesenchymal stem cells facilitate tubular epithelial cell dedifferentiation and growth via hepatocyte growth factor induction. PLOS ONE 2015, 10, e0121534. [CrossRef]

62. Zou, X.; Zhang, G.; Cheng, Z.; Yin, D.; Du, T.; Ju, G.; Miao, S.; Liu, G.; Lu, M.; Zhu, Y. Microvesicles derived from human Wharton's Jelly mesenchymal stromal cells ameliorate renal ischemia-reperfusion injury in rats by suppressing CX3CL1. Stem Cell Res. Ther. 2014, 5, 1-13. [CrossRef]

63. Grange, C.; Iampietro, C.; Bussolati, B. Stem cell extracellular vesicles and kidney injury. Stem Cell Investig. 2017, 4. [CrossRef]

64. Shen, B.; Liu, J.; Zhang, F.; Wang, Y.; Qin, Y.; Zhou, Z.; Qiu, J.; Fan, Y. CCR2 Positive Exosome Released by Mesenchymal Stem Cells Suppresses Macrophage Functions and Alleviates Ischemia/Reperfusion-Induced Renal Injury. Stem Cells Int. 2016, 2016, 1240301. [CrossRef]

65. Ranghino, A.; Bruno, S.; Bussolati, B.; Moggio, A.; Dimuccio, V.; Tapparo, M.; Biancone, L.; Gontero, P.; Frea, B.; Camussi, G. The effects of glomerular and tubular renal progenitors and derived extracellular vesicles on recovery from acute kidney injury. Stem Cell Res. Ther. 2017, 8, 1-15. [CrossRef] [PubMed]

66. Zhang, G.; Yang, Y.; Huang, Y.; Zhang, L.; Ling, Z.; Zhu, Y.; Wang, F.; Zou, X.; Chen, M. Hypoxia-induced extracellular vesicles mediate protection of remote ischemic preconditioning for renal ischemia-reperfusion injury. Biomed. Pharmacother. 2017, 90, 473-478. [CrossRef] [PubMed]

67. Wu, X.; Yan, T.; Wang, Z.; Wu, X.; Cao, G.; Zhang, C.; Tian, X.; Wang, J. Micro-vesicles derived from human Wharton's Jelly mesenchymal stromal cells mitigate renal ischemia-reperfusion injury in rats after cardiac death renal transplantation. J. Cell. Biochem. 2018, 119, 1879-1888. [CrossRef] [PubMed]

68. Gennai, S.; Monsel, A.; Hao, Q.; Park, J.; Matthay, M.A.; Lee, J.W. Microvesicles Derived from Human Mesenchymal Stem Cells Restore Alveolar Fluid Clearance in Human Lungs Rejected for Transplantation. Am. J. Transplant. 2015, 15, 2404-2412. [CrossRef] [PubMed]

69. Park, J.; Kim, S.; Lim, H.; Liu, A.; Hu, S.; Lee, J.; Zhuo, H.; Hao, Q.; Matthay, M.A.; Lee, J.-W. Therapeutic effects of human mesenchymal stem cell microvesicles in an ex vivo perfused human lung injured with severe E. coli pneumonia. Thorax 2019, 74, 43-50. [CrossRef] [PubMed]

70. Stone, M.L.; Zhao, Y.; Smith, J.R.; Weiss, M.L.; Kron, I.L.; Laubach, V.E.; Sharma, A.K. Mesenchymal stromal cell-derived extracellular vesicles attenuate lung ischemia-reperfusion injury and enhance reconditioning of donor lungs after circulatory death. Respir Res. 2017, 18, 212. [CrossRef]

71. Lonati, C.; Bassani, G.A.; Brambilla, D.; Leonardi, P.; Carlin, A.; Maggioni, M.; Zanella, A.; Dondossola, D.; Fonsato, V.; Grange, C.; et al. Mesenchymal stem cell-derived extracellular vesicles improve the molecular phenotype of isolated rat lungs during ischemia/reperfusion injury. J. Heart Lung Transplant. 2019, 38, 1306-1316. [CrossRef]

72. Rigo, F.; De Stefano, N.; Navarro-Tableros, V.; David, E.; Rizza, G.; Catalano, G.; Gilbo, N.; Maione, F.; Gonella, F.; Roggio, D.; et al. Extracellular Vesicles from Human Liver Stem Cells Reduce Injury in an Ex Vivo Normothermic Hypoxic Rat Liver Perfusion Model. Transplantation 2018, 102, e205-e210. [CrossRef]

73. Dipchand, A.I.; Rossano, J.W.; Edwards, L.B.; Kucheryavaya, A.Y.; Benden, C.; Goldfarb, S.; Levvey, B.J.; Lund, L.H.; Meiser, B.; Yusen, R.D.; et al. The Registry of the International Society for Heart and Lung Transplantation: Eighteenth Official Pediatric Heart Transplantation Report-2015; Focus Theme: Early Graft Failure. J. Hear. Lung Transplant. 2015, 34, 1233-1243. [CrossRef]

74. Krishnam, M.S.; Suh, R.D.; Tomasian, A.; Goldin, J.G.; Lai, C.; Brown, K.; Batra, P.; Aberle, D.R. Postoperative complications of lung transplantation: Radiologic findings along a time continuum. Radiographics 2007, 27, 957-974. [CrossRef]

75. Meyer, K.C. Recent advances in lung transplantation. F1000Research 2018, 7, 1684. [CrossRef] [PubMed] 
76. Zhu, Y.-G.; Feng, X.-M.; Abbott, J.; Fang, X.-H.; Hao, Q.; Monsel, A.; Qu, J.-M.; Matthay, M.A.; Lee, J.W. Human mesenchymal stem cell microvesicles for treatment of Escherichia coli endotoxin-induced acute lung injury in mice. Stem Cells 2014, 32, 116-125. [CrossRef] [PubMed]

77. Haga, H.; Yan, I.K.; Borelli, D.; Matsuda, A.; Parasramka, M.; Shukla, N.; Lee, D.D.; Patel, T. Extracellular vesicles from bone marrow-derived mesenchymal stem cells protect against murine hepatic ischemia/reperfusion injury. Liver Transpl. 2017, 23, 791-803. [CrossRef] [PubMed]

78. Du, Y.; Li, D.; Han, C.; Wu, H.; Xu, L.; Zhang, M.; Zhang, J.; Chen, X. Exosomes from Human-Induced Pluripotent Stem Cell-Derived Mesenchymal Stromal Cells (hiPSC-MSCs) Protect Liver against Hepatic Ischemia/Reperfusion Injury via Activating Sphingosine Kinase and Sphingosine-1-Phosphate Signaling Pathway. Cell. Physiol. Biochem. 2017, 43, 611-625. [CrossRef] [PubMed]

79. Anger, F.; Camara, M.; Ellinger, E.; Germer, C.T.; Schlegel, N.; Otto, C.; Klein, I. Human Mesenchymal Stromal Cell-Derived Extracellular Vesicles Improve Liver Regeneration after Ischemia Reperfusion Injury in Mice. Stem Cells Dev. 2019, 28, 1451-1462. [CrossRef]

80. Yao, J.; Zheng, J.; Cai, J.; Zeng, K.; Zhou, C.; Zhang, J.; Li, S.; Li, H.; Chen, L.; He, L.; et al. Extracellular vesicles derived from human umbilical cord mesenchymal stem cells alleviate rat hepatic ischemia-reperfusion injury by suppressing oxidative stress and neutrophil inflammatory response. FASEB J. 2019, 33, 1695-1710. [CrossRef]

81. Nawaz, M.; Fatima, F.; Vallabhaneni, K.C.; Penfornis, P.; Valadi, H.; Ekström, K.; Kholia, S.; Whitt, J.D.; Fernandes, J.D.; Pochampally, R.; et al. Extracellular Vesicles: Evolving Factors in Stem Cell Biology. Stem Cells Int. 2016, 2016, 1073140. [CrossRef]

82. Gray, W.D.; French, K.M.; Ghosh-Choudhary, S.; Maxwell, J.T.; Brown, M.E.; Platt, M.O.; Searles, C.D.; Davis, M.E. Identification of therapeutic covariant microRNA clusters in hypoxia-treated cardiac progenitor cell exosomes using systems biology. Circ. Res. 2015, 116, 255-263. [CrossRef]

83. Agarwal, U.; George, A.; Bhutani, S.; Ghosh-Choudhary, S.; Maxwell, J.T.; Brown, M.E.; Mehta, Y.; Platt, M.O.; Liang, Y.; Sahoo, S.; et al. Experimental, systems, and computational approaches to understanding the MicroRNA-mediated reparative potential of cardiac progenitor cell-derived exosomes from pediatric patients. Circ. Res. 2017, 120, 701-712. [CrossRef]

84. Vrijsen, K.R.; Sluijter, J.P.G.; Schuchardt, M.W.L.; van Balkom, B.W.M.; Noort, W.A.; Chamuleau, S.A.J.; Doevendans, P.A.F.M. Cardiomyocyte progenitor cell-derived exosomes stimulate migration of endothelial cells. J. Cell. Mol. Med. 2010, 14, 1064-1070. [CrossRef]

85. Bracco Gartner, T.C.L.; Deddens, J.C.; Mol, E.A.; Magin Ferrer, M.; van Laake, L.W.; Bouten, C.V.C.; Khademhosseini, A.; Doevendans, P.A.; Suyker, W.J.L.; Sluijter, J.P.G.; et al. Anti-fibrotic Effects of Cardiac Progenitor Cells in a 3D-Model of Human Cardiac Fibrosis. Front. Cardiovasc. Med. 2019, 6, 52. [CrossRef]

86. Arslan, F.; Lai, R.C.; Smeets, M.B.; Akeroyd, L.; Choo, A.; Aguor, E.N.E.; Timmers, L.; van Rijen, H.V.; Doevendans, P.A.; Pasterkamp, G.; et al. Mesenchymal stem cell-derived exosomes increase ATP levels, decrease oxidative stress and activate PI3K/Akt pathway to enhance myocardial viability and prevent adverse remodeling after myocardial ischemia/reperfusion injury. Stem Cell Res. 2013, 10, 301-312. [CrossRef] [PubMed]

87. Khosravi-Maharlooei, M.; Hajizadeh-Saffar, E.; Tahamtani, Y.; Basiri, M.; Montazeri, L.; Khalooghi, K.; Ashtiani, M.K.; Farrokhi, A.; Aghdami, N.; Nejad, A.S.H.; et al. THERAPY OF ENDOCRINE DISEASE: Islet transplantation for type 1 diabetes: So close and yet so far away. Eur. J. Endocrinol. 2015, 173, R165-R183. [CrossRef]

88. Nie, W.; Ma, X.; Yang, C.; Chen, Z.; Rong, P.; Wu, M.; Jiang, J.; Tan, M.; Yi, S.; Wang, W. Human mesenchymal-stem-cells-derived exosomes are important in enhancing porcine islet resistance to hypoxia. Xenotransplantation 2018, 25, e12405. [CrossRef] [PubMed]

89. Wen, D.; Peng, Y.; Liu, D.; Weizmann, Y.; Mahato, R.I.; Ph, D. Mesenchymal stem cell and derived exosome as small RNA carrier and Immunomodulator to improve islet transplantation. J. Control. Release 2016, 238, 166-175. [CrossRef]

90. Biancone, L.; Bruno, S.; Deregibus, M.C.; Tetta, C.; Camussi, G. Therapeutic potential of mesenchymal stem cell-derived microvesicles. Nephrol. Dial. Transplant 2012, 27, 3037-3042. [CrossRef] [PubMed]

91. Aggarwal, S.; Pittenger, M.F. Human mesenchymal stem cells modulate allogeneic immune cell responses. Blood 2005, 105, 1815-1822. [CrossRef] 
92. Djouad, F.; Charbonnier, L.-M.; Bouffi, C.; Louis-Plence, P.; Bony, C.; Apparailly, F.; Cantos, C.; Jorgensen, C.; Noël, D. Mesenchymal stem cells inhibit the differentiation of dendritic cells through an interleukin-6-dependent mechanism. Stem Cells 2007, 25, 2025-2032. [CrossRef]

93. Selmani, Z.; Naji, A.; Zidi, I.; Favier, B.; Gaiffe, E.; Obert, L.; Borg, C.; Saas, P.; Tiberghien, P.; Rouas-Freiss, N.; et al. Human leukocyte antigen-G5 secretion by human mesenchymal stem cells is required to suppress $\mathrm{T}$ lymphocyte and natural killer function and to induce CD4+CD25highFOXP3+ regulatory T cells. Stem Cells 2008, 26, 212-222. [CrossRef]

94. Fujii, S.; Miura, Y.; Fujishiro, A.; Shindo, T.; Shimazu, Y.; Hirai, H.; Tahara, H.; Takaori-Kondo, A.; Ichinohe, T.; Maekawa, T. Graft-Versus-Host Disease Amelioration by Human Bone Marrow Mesenchymal Stromal/Stem Cell-Derived Extracellular Vesicles Is Associated with Peripheral Preservation of Naive T Cell Populations. Stem Cells 2018, 36, 434-445. [CrossRef]

(C) 2020 by the authors. Licensee MDPI, Basel, Switzerland. This article is an open access article distributed under the terms and conditions of the Creative Commons Attribution (CC BY) license (http://creativecommons.org/licenses/by/4.0/). 